\title{
The Production of Compost from Organic Wastes using Bioactivators and Its Application to Celery (Apium graveolens L.) Plant
}

\author{
Sri Indrayani, Nuriyanah, Lisyeu Nurjanah, Heru Wibowo, Dody Priadi ${ }^{1}$ \\ Research Center for Biotechnology-LIPI, Indonesia
}

\begin{abstract}
ABSTRAK
Dilakukan pembuatan pupuk kompos dari limbah Jerami padi sawah percobaan dan seresah daun tanaman buah-buahan kebun plasma nutfah Cibinong Science Center-Botanic Garden (CSC-BG) LIPI menggunakan bioaktivator StarTmik@OK dan Tricho Plus (LIPI) dan Promi (produk komersial). Kompos yang dihasilkan diaplikasikan kepada tanaman seledri (Apium graveolens L.) di rumah kasa (screenhouse) Puslit Bioteknologi-LIPI Cibinong, Kabupaten Bogor, Jawa Barat. Parameter pertumbuhan yang diamati adalah tinggi tanaman, jumlah petiol daun, dan biomassa. Penelitian disusun berdasarkan Rancangan Acak Lengkap (RAL) dengan tiga ulangan. Data hasil penelitian dianalisis secara statistik menggunakan SPSS ver. 24 dilanjutkan dengan uji jarak berganda Duncan (DMRT). Hasil menunjukkan bahwa secara umum kompos yang berasal dari jerami padi dengan menggunakan berbagai bioaktivator menghasilkan nilai rataan pertumbuhan tertinggi yaitu tinggi tanaman $(35,7 \mathrm{~cm})$, jumlah petiol $(23,7)$, dan biomassa (42,3 g) dibandingkan dengan kompos yang menggunakan bahan lainnya. Penggunaan pupuk kimia masih diperlukan untuk meningkatkan pertumbuhan tanaman seledri.
\end{abstract}

Kata kunci: Apium graveolens L., Bioaktivator, Kompos, Limbah Organik, Seledri

\begin{abstract}
The organic waste of rice straw from the experimental paddy field and broadleaf litter from the fruit germplasm garden of Cibinong Science Center-Botanic Garden (CSC-BG) was processed into compost with the addition of bioactivators. The bioactivator of StarTmik@OK and Tricho Plus (LIPI) and Promi (commercial product) was added to the composting raw materials. Produced compost was then applied to celery (Apium graveolens L.) plants in the screenhouse of RD Center for Biotechnology-LIPI. The growth parameters observed were plant height, leaf petiole, and biomass. The experiment was arranged in a Completely Randomized Design (CRD) with three replications. Obtained data were statistically analyzed using SPSS ver.24, followed by Duncan's multiple range tests (DMRT). The result showed that the highest growth rates, i.e., plant height (35.7 $\mathrm{cm})$, number of petiol (23.7), dan biomass (42.3 g), were obtained by using rice straw compost using various bioactivators. Meanwhile, chemical fertilizer is still needed to increase the growth of celery plants.
\end{abstract}

Keywords: Apium graveolens L., Bioactivator, Celery, Compost, Organic Waste

Citation: Indrayani, S., Nuriyanah, Nurjanah, L., Wibowo, H. dan Priadi, D. (2021). The Production of Compost from Organic Wastes using Bioactivators and Its Application to Celery (Apium graveolens L.) Plant. Jurnal Ilmu Lingkungan, 19(2), 479-484, doi:10.14710/jil.19.2.479-484

\section{Introduction}

Celery (Apium graveolens L.) (Apiaceae) is known as a flavour-enhancing and food garnish. The leaves contain flavonoids, saponins, and polyphenols, so that also used for herbal medicine and cosmetics. The main flavonoid compound is apigenin (Yan, et al. 2014). Celery is used as herbal medicine to lower blood pressure in people with hypertension, preventing colds, and others. Herbal treatment is considered safer than modern medicine because of its lower side effects. The side effects of herbal medicines can be reduced by using suitable types of herbs, the right dosage, and accurate analysis information (Sari, 2006). Celery has also been used as an ingredient in shampoos and creams because it contains nutrients and blackens hair (Permadi, 2006).
Compost is the result of the decomposition process of plant and animal. Compost can increase soil fertility, soil structure, diversity and number of microorganisms, water absorption and retention, and soil binding capacity for nutrients (Yuliarti, 2009; Hendrika, et al. 2017).

Compost contains complete nutrients to provide nutrients for microorganisms (Indriani, 2007). Previous research on compost and its application has not specifically combined the types of compost materials and bio activators used and their application to celery plants. Compost maturity can be accelerated by adding bioactivators such as animal manure or a consortium of microorganisms, as a study conducted by Priadi \& Ermayanti (2014). A study conducted by Hindersah et al. (2011) proved that bioactivators could improve the microbiological quality of compost.

1 Penulis korespondensi: dody004@gmail.com 
Research on organic fertilizers on celery growth in screenhouse conditions on non-soil media has been carried out by Adawiyah \& Afa (2018). Meanwhile, Syam et al. (2017) and Yusuf (2017) carried out experiments in the open field. The increasing need for vegetables due to the population growth is an opportunity for celery cultivation in the lowlands using organic fertilizers (Edi, 2009).

The objective of the study is to identify the best combination of compost raw materials and bioactivator on compost for celery plant growth in the screenhouse.

\section{Materials and Methods}

The research was conducted at the screenhouse of the Research Center for Biotechnology-LIPI, Cibinong (6²9'48"Latitude and 106 $50^{\circ} 46^{\prime \prime}$ Longitude), West Java.

\subsection{Organic Materials}

The compost was made from rice straw, and the broadleaf fruit plant of Java Apple (Syzygium aqueum) and matoa (Pometia pinnata) were obtained from experimental rice fields and fruit germplasm garden of Cibinong Science Center-Botanical Garden (CSC-BG). The bioactivators used were StarTmik @ OK and Tricho Plus (LIPI) and Promi (commercial product). In the composting process, no animal manure is added to prevent the effect of animal manure microorganisms on the composting process (Table 1 ).

The seeds of hybrid celery (Apium graveolens L.) "Amigo" (East-West Seed) with 80\% viability, 98\% purity, and $7 \%$ moisture content were used in this study. Celery seeds were obtained from agricultural shops in Bogor, West Java.

\subsection{Equipment Used}

During the composting process, the raw materials of the compost were covered with tarpaulin to maintain their temperature and humidity. The temperature and humidity of the composting process were monitored using a digital thermometer and hygrometer.

\subsection{Compost Preparation}

The raw materials of compost were chopped and moistened prior aerobic composting process. Temperature and humidity were monitored weekly up to the end of the composting process.

\subsection{Chemical Analysis of Compost}

Mature compost was chemically analyzed in Laboratory of Plant Ecology, R\&D Center for Biology-LIPI.

\subsection{Experimental design and data analysis}

The study was using a Randomized Complete Design (RCD) factorial with three replications. The first factor was six combinations of raw materials of compost, and the second factor was three growth parameters (plant height, number of petiols, and biomass).

Obtained data were analyzed using Anova followed by Duncan's Multiple Range Test using SPSS ver. 24 software.

\section{Result and Discussion}

\subsection{Water Content and pH of Compost Raw Materials.}

Prior composting process, the raw materials of the compost were measured for water content and $\mathrm{pH}$. as described in Table 1 . Water content and $\mathrm{pH}$ of raw materials are ranged from $57.2-78.0 \%$ and $6.05-6.45$ respectively (Table 1). According to Binner (2016), the optimum water content depends on local conditions. However, in most cases is in the range of $50-60 \%$. The biological degradation will stop if there is too less water available. Furthermore, the $\mathrm{pH}$ value is influenced by waste properties.

\subsection{Chemical content of mature compost}

The results of compost chemical analysis (Table 2) showed that the total value of macronutrients (N, P, and $\mathrm{K}$ ) did not meet the standard quality of organic fertilizers (min. 4\%) and the water content (max. $25 \%$ ). However, the $\mathrm{C} / \mathrm{N}$ ratio of the compost met the quality standards of organic fertilizers according to Kementerian Pertanian RI: Permentan Decree No. 70/Permentan/SR.140/10/2011). The deficiency of these macronutrients will be overcome by adding NPK fertilizers to the growing media periodically. Meanwhile, the optimum moisture content can be achieved by drying the compost to $15-25 \%$ moisture content.

Table 1. Initial Water Content and pH of Compost Raw Materials using Several Bioactivators

\begin{tabular}{|c|c|c|c|c|}
\hline No. & Code & $\begin{array}{l}\text { Organic waste } \\
+ \text { Bioactivator }\end{array}$ & $\begin{array}{l}\text { Water } \\
\text { content } \\
(\%)\end{array}$ & $\mathrm{pH}$ \\
\hline 1 & $\mathrm{~J} 1$ & $\begin{array}{l}\text { Rice Straw + } \\
\text { Promi }\end{array}$ & 57,2 & 6.32 \\
\hline 2 & $\mathrm{~J} 2$ & $\begin{array}{l}\text { Rice Straw + } \\
\text { StarTmik@OK+ }\end{array}$ & 57,5 & 6.16 \\
\hline 3 & J3 & $\begin{array}{l}\text { Rice Straw + } \\
\text { Tricho Plus }\end{array}$ & 76,6 & 6.05 \\
\hline 4 & D1 & $\begin{array}{l}\text { Broadleaf Litter } \\
\text { + Promi }\end{array}$ & 78,0 & 6.24 \\
\hline 5 & D2 & $\begin{array}{l}\text { Broadleaf Litter } \\
\text { + StarTmik@OK }\end{array}$ & 57,4 & 6.31 \\
\hline 6 & D3 & $\begin{array}{l}\text { Broadleaf Litter } \\
+ \text { Tricho Plus }\end{array}$ & 76,0 & 6.45 \\
\hline
\end{tabular}




\subsection{Plant height}

The results showed that the mean height of all celery plants increased up to the end of the observation. At week 13, the highest plants $(35.7 \mathrm{~cm})$ were obtained from J1 treatment, which indicated that the nutrients contained in straw (J1) were the most optimal for celery growth (Figure 1). According to Syahrudin (2011), plant height was affected by balanced nutrient availability in the soil. In addition, the rate of photosynthesis will produce photosynthate to increase the plant height (Mas'ud, 1992). The lowest plants were obtained from soil (control) $(17.7 \mathrm{~cm})$ due to the nutrients available in the soil were insufficient for maximum plant growth.

\subsection{Number of leaf petioles}

Nitrogen is needed for vegetative growth. Nitrogen is a building block for proteins, nucleic acids, and chlorophyll to grow celery plant leaf petiole (Rina, 2015). Figure 1B shows that the highest leaf petiole number is obtained from rice straw compost (J1). It can also improve soil biological properties to provide a better root environment (Pangaribuan \& Pujisiswanto, 2008). The opposite results were found in a study conducted by Fitrah \& Amir (2015), which is that the growth of celery on straw compost media is lower than organic plus fertilizer. It is assumed that the organic plus fertilizer is richer in nutrients than rice straw. Figure 1B showed that a decrease in the number of leaf petioles. Pests and diseases have attacked during the experiment affected the growth of celery plants such as Aphids (Aphis craccivera), mealybugs (Bemisia tabaci), mites (Spydermites), and armyworms (Spodoptera sp.) in the seventh week. The pests caused the celery leaves to turn yellow, curly and some of the leaves were eaten by armyworms. It was also found stem rot disease.

Table 2. Water Content and pH of Organic Wastes as Raw Material of Compost

\begin{tabular}{cclcc}
\hline \hline No. & Code & \multicolumn{1}{c}{ Organic waste + Bioactivator } & $\begin{array}{c}\text { Water content } \\
\mathbf{( \% )}\end{array}$ & pH \\
\hline 1 & J1 & Rice Straw + Promi & 57,2 & 6.32 \\
2 & J2 & Rice Straw + StarTmik@OK+ & 57,5 & 6.16 \\
3 & J3 & Rice Straw + Tricho Plus & 76,6 & 6.05 \\
4 & D1 & Broadleaf Litter + Promi & 78,0 & 6.24 \\
5 & D2 & Broadleaf Litter + StarTmik@OK & 57,4 & 6.31 \\
6 & D3 & Broadleaf Litter + Tricho Plus & 76,0 & 6.45 \\
\hline
\end{tabular}

Table 3. Chemical Content of Compost Applied to Celery Plant

\begin{tabular}{|c|c|c|c|c|c|c|c|c|c|}
\hline Code & $\begin{array}{c}\mathrm{P}_{2} \mathrm{O}_{5} \\
(\mathrm{ppm})\end{array}$ & $\begin{array}{c}\mathrm{K}_{2} \mathrm{O} \\
(\mathrm{ppm})\end{array}$ & $\begin{array}{c}\text { Total Ca } \\
(\%)\end{array}$ & $\begin{array}{c}\text { Total Mg } \\
(\%)\end{array}$ & $\begin{array}{c}\mathrm{C} \\
(\%)\end{array}$ & $\begin{array}{c}\mathrm{N} \\
(\%)\end{array}$ & $\mathrm{C} / \mathrm{N}$ & $\mathbf{p H}$ & $\begin{array}{c}\text { Water } \\
\text { content (\%) }\end{array}$ \\
\hline J1 & 282.97 & 274.86 & 0.074 & 0.067 & 27.74 & 1.59 & 17.45 & 6.32 & 57.17 \\
\hline $\mathrm{J} 2$ & 299.70 & 277.68 & 0.096 & 0.068 & 28.95 & 1.57 & 18.47 & 6.16 & 57.49 \\
\hline $\mathrm{J} 3$ & 328.73 & 270.78 & 0.158 & 0.068 & 24.36 & 1.52 & 16.03 & 6.05 & 76.57 \\
\hline D1 & 237.38 & 260.86 & 0.556 & 0.066 & 25.34 & 1.18 & 21.53 & 6.24 & 78.02 \\
\hline D2 & 275.24 & 239.82 & 0.510 & 0.066 & 28.75 & 1.25 & 22.92 & 6.31 & 57.37 \\
\hline D3 & 223.73 & 256.04 & 0.226 & 0.066 & 21.61 & 1.23 & 17.53 & 6.45 & 75.99 \\
\hline
\end{tabular}
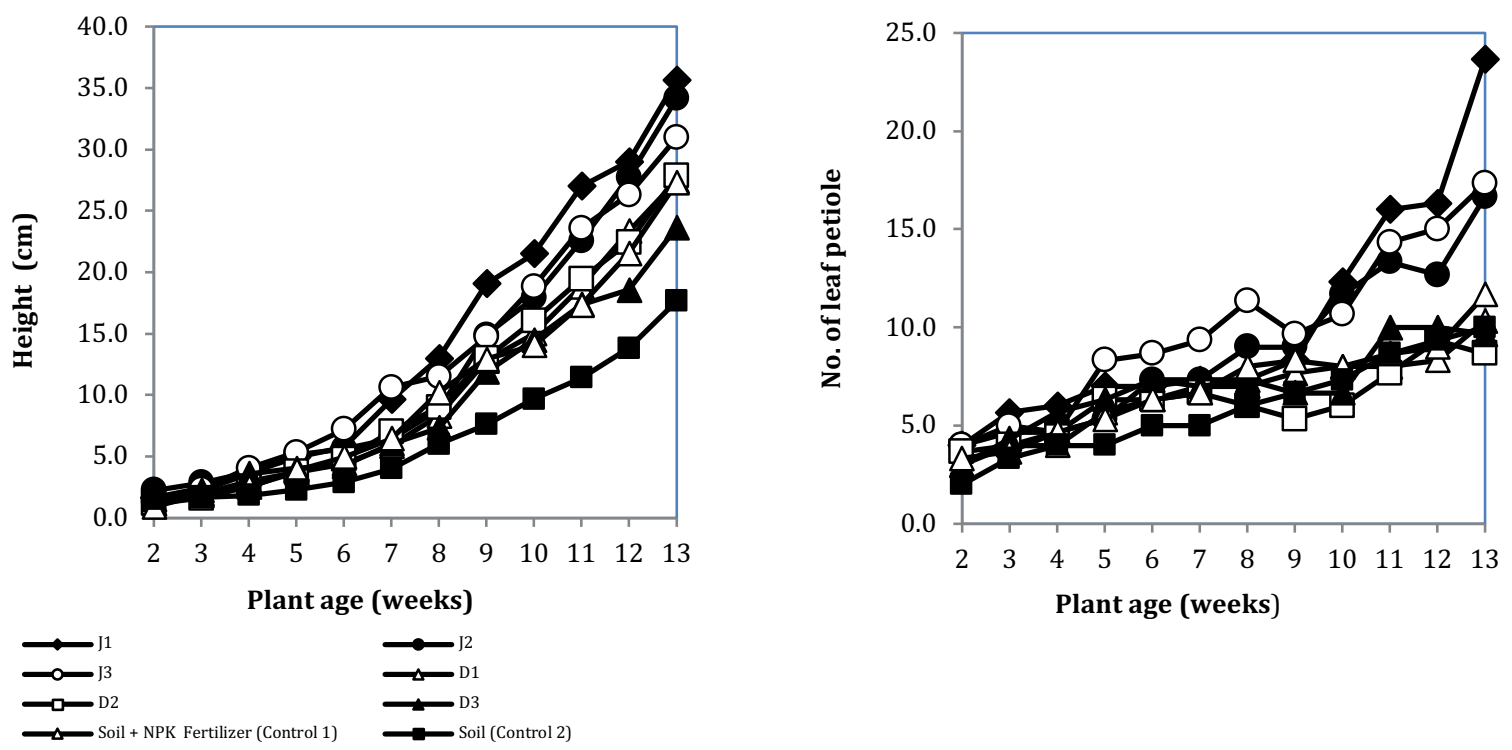

Figure 1. A. Plant height and B. Number of leaf petiole of celery on various growth media upto 13 weeks 


\subsection{Biomass}

Plant biomass was affected by water content in plants. Water in plant cells is needed by plants to grow optimally. According to Mutryarny et al. (2014), plant biomass is influenced by plant moisture. The need for water at each phase of plant growth is related to physiological processes, morphology, and environmental factors. (Jumin, 2008). The highest biomass of celery was shown in treatment J1. (Figure 2). These conditions indicate that the nutrients in the rice straw compost can provide nutrients to support growth and increase plant production. According to Agustina (1990), the adequacy and availability of nutrients determine the rate of plant growth and production, while nitrogen deficiency will cause a decrease in vegetative growth and production. The growth and development of plant organs will be more optimal if the nutrient needs are sufficient (Lakitan, 2007). The lowest biomass was obtained from plants on soil media (Control 2). In this medium, celery plants have nutrient deficiency. The growth of celery for 13 weeks can be seen in Table 3 .

Rice straw compost media (J1) produced the highest plant growth rate, which was not significantly different from other media containing rice straw compost. The $\mathrm{C} / \mathrm{N}$ ratio of rice straw compost ranged from 16.03 to 18.47 and met the quality standards for organic fertilizers (Table 2). This result was the same as a study by Yasin et al. (2019). The nutrient is needed to form organs in plants (Sumarni and Rosliani, 2001). The results showed no significant difference in all treatments with controls on plant height. The treatment of rice straw-promi compost was not significantly different from the rice straw-
StarTmik@OK and rice straw-Tricho Plus compost in the number of the leaf petiole. Biomass in the rice straw-promi compost was not significantly different from other organic fertilizer treatments and NPK (control 1) but significantly different with the treatment of broadleaf litter-StarTmik @ OK compost and soil (control). The growth of celery in soil without the addition of NPK was lower than that of soil added with NPK, although it was not significantly different.

Celery grown in rice straw-Tricho Plus compost media was better than other compost in terms of growth and yield as indicated by plant height $(35.7 \mathrm{~cm})$, number of broadleaf litter (23.7), and biomass (42.3 grams). The nutrient levels caused in each of these treatments are different. Therefore, the response of the plants is different. The results of the compost nutrient analysis (Table 3 ) show that the total $\mathrm{N}$ and $\mathrm{K}$ of rice straw are higher than the broadleaf litter. The total $\mathrm{N}$ content in J1 was higher than the treatment J2, J3, D1, D2, and D3 (1.59\%). The addition of macronutrients such as nitrogen, phosphorus, and potassium in higher concentrations to the growing medium will support better plant growth, as indicated in plant height and leaf petioles. According to Lingga and Marsono (2010), nitrogen affected the growth and development of leaves and stimulated overall growth. The appearance of celery plants in rice straw compost media (J1) compared to Control 2 and 1 is presented in Figure 4. Nitrogen (N), as well as phosphorus (P), is required for protein formation (Rosmarkam and Yuwono, 2002). However, according to Chen (2006), organic fertilizers can be integrated with chemical fertilizers to realize balanced nutrient management for optimal plant growth.

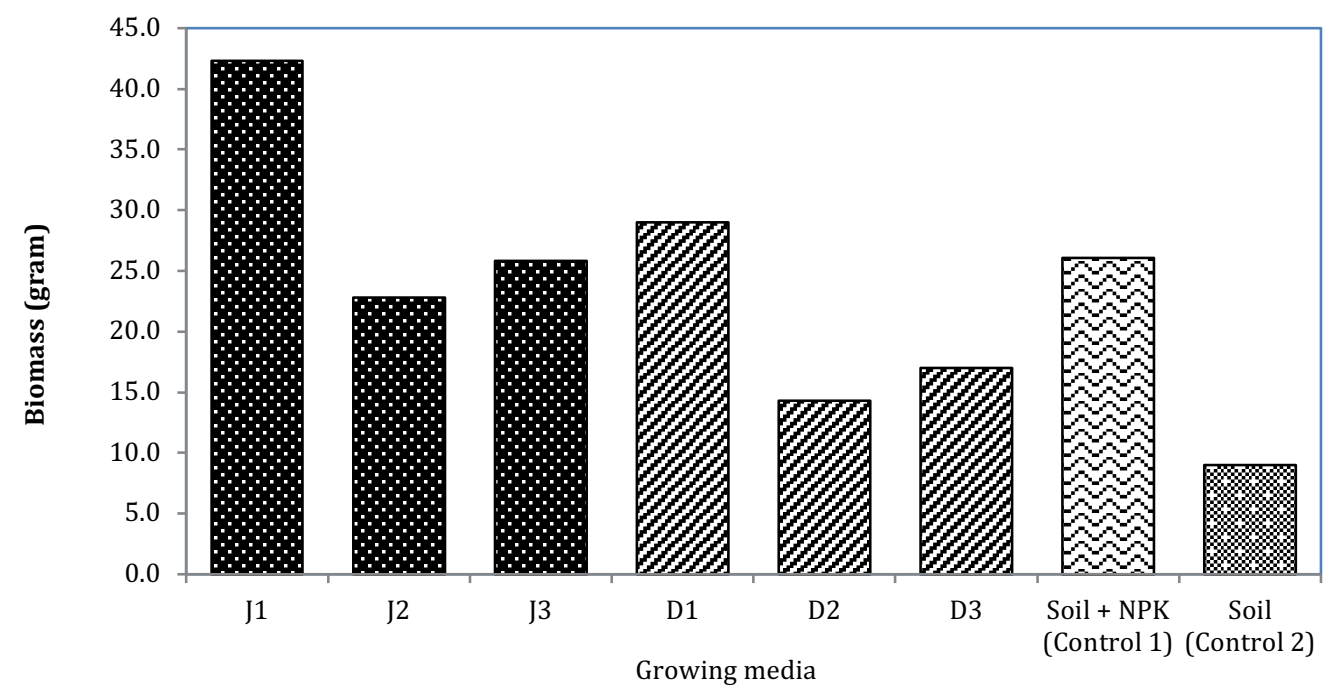

Figure 2. Biomass of celery plants harvested in weeks 13 
Table 4. Growth of Celery Plant in Various Growing Media up to 13 Weeks

\begin{tabular}{cccc}
\hline \multirow{2}{*}{ Growing media } & \multicolumn{3}{c}{ Growth Parameters } \\
\cline { 2 - 4 } & $\begin{array}{c}\text { Plant height } \\
(\mathrm{cm})\end{array}$ & $\begin{array}{c}\text { Number of leaf } \\
\text { petiole }\end{array}$ & $\begin{array}{c}\text { Biomass } \\
\text { (gram) }\end{array}$ \\
\hline J1 & $35.7 \mathrm{a}$ & $23.7 \mathrm{a}$ & $42.3 \mathrm{a}$ \\
$\mathrm{J} 2$ & $34.2 \mathrm{a}$ & $16.7 \mathrm{ab}$ & $22.8 \mathrm{ab}$ \\
J3 & $31.0 \mathrm{a}$ & $17.3 \mathrm{ab}$ & $25.8 \mathrm{ab}$ \\
D1 & $27.5 \mathrm{a}$ & $10.3 \mathrm{~b}$ & $29.0 \mathrm{ab}$ \\
D2 & $27.8 \mathrm{a}$ & $8.7 \mathrm{~b}$ & $14.3 \mathrm{~b}$ \\
D3 & $23.7 \mathrm{a}$ & $9.7 \mathrm{~b}$ & $17.0 \mathrm{ab}$ \\
Control 1* & $27.3 \mathrm{a}$ & $11.7 \mathrm{~b}$ & $26.7 \mathrm{ab}$ \\
Control 2** & $17.7 \mathrm{a}$ & $10.0 \mathrm{~b}$ & $9.0 \mathrm{~b}$ \\
\hline
\end{tabular}

Note:

- Mean in the same column(s) followed by the different letters are significantly different $(\mathrm{p}<0.05)$ following

Duncan's Multiple Range Test (DMRT)

* = Soil + NPK

$* *$ Soil
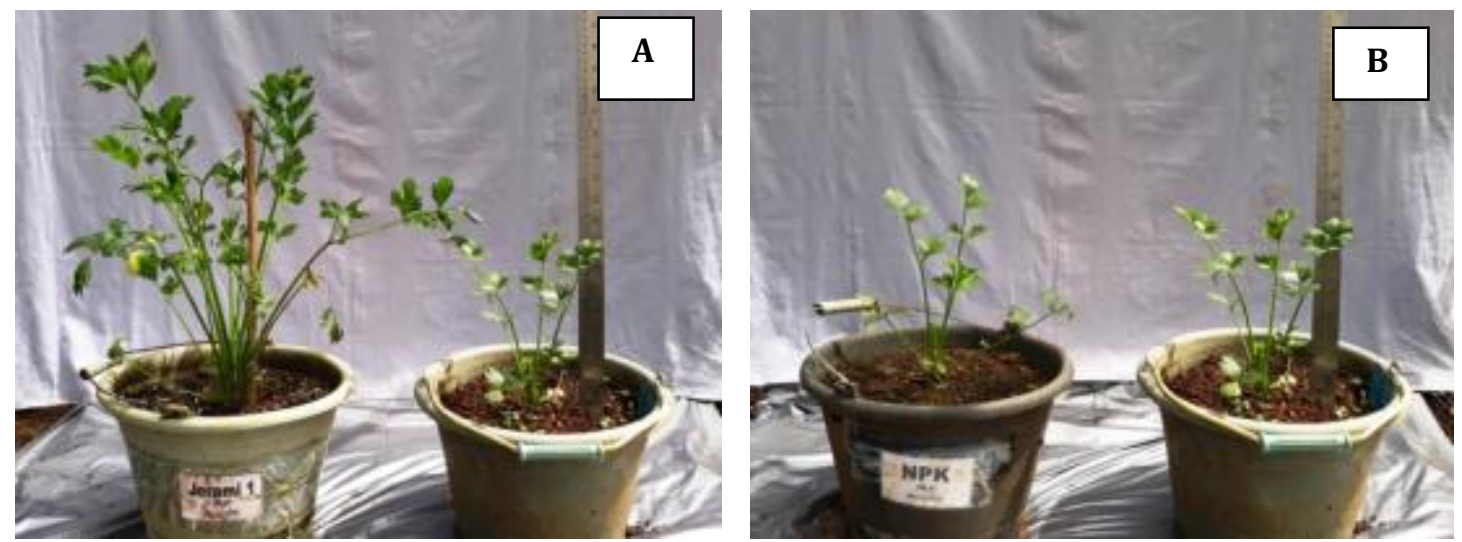

Figure 4. Celery plants in growing media A. J1 (Rice Straw + Promi) compost vs Control 2 (Soil); and B. Control 1 (Soil + NPK) vs Control 2 (Soil) in weeks 13

\section{Conclusion}

The total value of macronutrients of the produced compost did not meet the standard quality of organic fertilizers. At the same time, the $\mathrm{C} / \mathrm{N}$ ratio of the compost met the quality standards of organic fertilizers according to Permentan Decree.

Compost made from rice straw waste resulted in better growth on celery plant than the compost made from the broadleaf litter of fruit plant germplasm using various bioactivators. Meanwhile, chemical fertilizer is still needed to increase the growth of celery plants.

\section{Aknowledgements}

The authors would like to thank Fiqolbi Nuro, M.Si. as a compost production coordinator, for providing compost for the experiment. Thanks also to Mr. Ajum and Mr. Yadi for their assistance in maintaining celery plants in the screenhouse.

\section{References}

Adawiyah, R., \& Afa, M. (2018). Pertumbuhan Tanaman Seledri (Apium graveolens L.) pada Berbagai Media Tanam Tanpa Tanah dengan Aplikasi Pupuk Organik
Cair (POC). BioWallacea: Jurnal Penelitian Biologi, 5(1), 750-760.

Agustina, L. (1990). Nutrisi Tanaman, Rineka Cipta, Jakarta.

Binner, E. (2016). Lessons learned-how to produce quality compost. Sustainable Sanitation Practice, 26, 4-15.

Chen, J. H. (2006). The Combined Use of Chemical and Organic Fertilizers and/or Biofertilizer for Crop Growth and Soil Fertility. International workshop on sustained management of the soil-rhizosphere system for efficient crop production and fertilizer use, Land Development Department Bangkok Thailand.

Edi, S. (2009). Teknologi Budidaya Seledri Dataran Rendah. Balai Pengkajian Teknologi Pertanian Jambi

Fitrah, A., \& Amir, N. (2015). Effect of Solid and Liquid Organic Fertilizer on the Growth and Production Plant Celery (Apium graveolens L.) di Polybag. Klorofil: Jurnal Penelitian Ilmu-Ilmu Pertanian, 10(1), 43-48.

Hendrika, G., A. Rahayu, \& Mulyaningsih, Y. (2017). Pertumbuhan Tanaman Seledri (Apium graveolens L.) pada Berbagai Komposisi Pupuk Organik dan Sintetik. Jurnal Agronida, 3 (1), 1-9.

Hindersah, R., Hernanto Y., \& Joy B., Mulyani, O. (2018). Utilization of Tofu Waste in Composting of household Waste for Increasing Quality of Compost Microbiology, Agrinimal, 15-21.

Indriani, Y.H. (2007). Membuat Kompos Secara Kilat. Jakarta: Penebar Swadaya.

Jumin, H. (2008). Agronomi. Raja Grafindo Persada. Jakarta. 
Kementerian Pertanian RI (2011). Permentan No.70/Permentan/SR.140/10/2011 tentang Pupuk Organik, Pupuk Hayati dan Pembenah Tanah.

Lakitan, N. (2007). Dasar-dasar Fisiologi Tumbuhan. Raja Grafindo. Jakarta.

Lingga, P., \& Marsono. (2010). Petunjuk Penggunaan Pupuk. Seri Agritekno. Penebar Swadaya, Jakarta:

Mas'ud. (1992). Telaah Kesuburan Tanah. Angkasa, Yogyakarta

Mutryarny, E., Endriani, E., \& Lestari, S. U. (2014). Pemanfaatan Urine Kelinci untuk Meningkatkan Pertumbuhan dan Produksi Tanaman Sawi (Brassica juncea L) Varietas Tosakan, Jurnal Ilmiah Pertanian, 11(2), 23-34.

Pangaribuan, D., \& Pujisiswanto, H. (2008). Pemanfaatan Kompos Jerami untuk Meningkatkan Produksi dan Kualitas Buah Tomat. Prosiding Seminar Nasional Sains dan Teknologi-II. Universitas Lampung, vol. 7, no. 1.

Permadi, A. (2006). 36 Resep Tumbuhan Obat untuk Menurunkan Kolesterol. Penebar Swadaya, Jakarta:

Priadi, D., \& Ermayanti, T. M. (2014). Pembuatan Kompos Berbahan Dasar Potongan Rumput dan Kotoran Sapi serta Pemanfaatannya Untuk Tanaman Sayuran. dalam Prosiding Seminar Nasional Hasil Penelitian Unggulan Bidang Pangan Nabati Bogor, vol. 25, pp. 169-178.

Rina, D. (2015). Manfaat Unsur N, P, dan K bagi Tanaman. Balai Litbang Pertanian Kalimantan Timur Kementrian Pertanian Republik Indonesia.

Rosmarkam, A. dan N.W. Yuwono. 2002. Ilmu Kesuburan Tanah. Kanisus, Yogyakarta.
Sari, L. O. R. K. (2012). Pemanfaatan Obat Tradisional dengan Pertimbangan Manfaat dan Keamanannya. Pharmaceutical Sciences and Research (PSR), 3(1), 1-7.

Sumarni, N. \& Rosliani, R. (2001). Media Tumbuh dan Waktu Aplikasi Larutan Hara Penanaman Cabai Secara Hidroponik. J. Hort, 11(4), 237-243.

Syahrudin. 2011. Respon Tanaman Seledri (Apium graveolens L.) terhadap Pemberian Beberapa Macam Pupuk Daun pada Tiga Jenis Tanah. Jurnal Universitas Palangkaraya, Fakultas Pertanian,12(1).

Syam, N., Suriyanti, S., \& Killian, L. H. (2017). Pengaruh Jenis Pupuk Organik dan Urea terhadap Pertumbuhan dan Hasil Tanaman Seledri (Apium graveolens L.). Agrotek 1(2), 43-53.

Yan, J., Yu, L., Xu, S., Gu, W., \& Zhu, W. (2014). Apigenin Accumulation and Expression Analysis of Apigenin Biosynthesis Relative Genes in Celery. Scientia Horticulturae, 165, 218-224.

Yasin, S. M., Kasim, N. N., Sapareng, S., \& Jabal, J. (2019). Pengaruh Bioaktivator dalam Proses Pengomposan Jerami Padi. Journal TABARO Agriculture Science, 3(1), 287-294.

Yuliarti, N. 2009. 1001 Cara Menghasilkan Pupuk Organik. Lily Publisher, Yogyakarta.

Yusuf, M. (2017). Respon Pertumbuhan dan Hasil Tanaman Seledri (Apium graveolens L.) pada Perlakuan Beberapa Media Tanam dan Pupuk Organik Cair. Jurnal Agrium Unimal, 14(1), 43-56. 